\title{
9
}

\section{JUSTICE AS A CRUCIAL \\ FORMAL AND INFORMAL \\ ELEMENT OF MANAGEMENT CONTROL SYSTEMS}

\author{
Natàlia Cugueró-Escofet \\ (IESE Business School - University of Navarra) $\mathcal{E}^{\circ}$ \\ Josep Maria Rosanas \\ (IESE Business School - University of Navarra)
}

Abstract: Management control systems include justice implicitly, as they believe that the market provides what is just or not through the market value. Psychological literature has deemed that people can perceive which procedures and decisions are just or not. In this paper, we argue that management control systems need to include justice criteria explicitly, beyond mere market value, in both their design (formal justice) and use (informal justice). This will increase the probability that organizational members will collaborate to achieve organizational goals.

Keywords: Management control systems (MCS), organizational justice, goal congruence, incentives, interest alignment. 


\section{INTRODUCTION}

The main objective of Management control systems (MCS) is to motivate managers to pursue long-term organizational objectives. Managers need to act in ways that ensure that those organizational objectives are more likely to be achieved. MCS include elements that are purely formal, which are part of their design, as well as other informal elements that must be included as they are used in day-to-day organizational managerial activities (Anthony $\sigma^{\circ}$ Govindarajan, 2003, 98).

Formal elements of MCS have increased in complexity to include intangibles, and have been rendered more sophisticated to capture those intangibles in specific measures; these systems are called balanced scorecards (Kaplan $\sigma^{\circ}$ Norton, $1992 \sigma^{\circ}$ 1993). Balanced scorecards were designed to improve strategic processes and to help managers to focus on the organization's objectives (Epstein $60^{\circ}$ Manzoni, 1997, Kaplan, 1996). Informal elements of MCS have been investigated through the understanding of the possible ways managers use MCS (Chapman, 1998). Managers use MCS to try to avoid risks (Chapman, 1998) and also to allow the company to develop, grow, and innovate (Bisbe $\sigma^{\circ}$ Otley, 2004, Davila, 2000, Davila et al., 2009), especially in the early stages of company development (Davila, 2005).

A special case of MCS is the one used for human resources management. Organizational scholars have studied how the outcomes of those systems have been perceived as being fair or not by employees in a new field that has been labeled organizational justice (Greenberg, 1987).

The literature on organizational justice studies individual perceptions of justice from different facets of the organizations and their agents. Studies in this field have found perceptions of justice to be related to behaviors that can help further organizational objectives and perceptions of injustice to be generators of harmful effects such as retaliation and litigation against the organization (Colquitt et al., 2001, Greenberg, 1987).

Organizational justice has advanced towards a deeper knowledge of how to frame processes and decisions that can potentially generate perceptions of justice or avoid perceptions of injustice. The findings suggest how to include justice in human resources management systems and processes to generate greater perceptions of justice. It is necessary, however, to find ways to justify how to consider justice ex-ante as an element of MCS, and to determine in which dimensions this justice must be present. Another issue is the crucial variables of MCS that benefit from including justice. 
Looking at the literature that has concentrated on linking MCS and fairness or justice, we have found some measures of the perceptions of justice that have been proposed to be included in MCS (a survey of these papers from 1990 can be found in Cugueró-Escofet and Rosanas, 2011). But there is a need to more clearly develop the inclusion of justice in a more conceptual way. In a classic paper, Vancil started to think about considering justice and goal congruence together (1973). Vancil stated that goal congruence and justice would be the basic criteria to evaluate MCS, but he did not a specifically outline what role is played by both justice and goal congruence when evaluating MCS.

Later on, in different studies, two authors argued the need to place concepts of justice at the core of MCS theories (Williams, 1987, Pallot, 1991). They recommend that competing MCS designs must be discussed in terms of criteria of justice which are explicitly outlined. Resources are allocated precisely by using MCS design, and thus the criteria of justice behind these distributions should not remain implicit but need to be explicitly discussed.

We totally agree with them and follow their advice. But we also go one step further for two reasons: first, because we think that justice is more than merely allocating resources. We propose a concept of justice that extends to encompass the allocation of resources, processes, rewards, and in general, any possible recognition received by people. And secondly, we also agree with Vancil that goal congruence, or its more updated version, interest alignment between organizations and their members, needs to be included in the proposal as well.

Our aim is to merge three bodies of literature: the incipient literature on MCS and justice, the literature on organizational justice, and the classic MCS literature. Going one step backward and trying to integrate these three pathways will greatly contribute to the role of justice in MCS, and it may also create a fruitful new stream of research that can address the current problems of organizational justice and MCS research.

In this paper we shall proceed as follows: First, we are going to explore and examine the main concepts regarding MCS and justice to show that they have remained largely separate. Secondly, we are going to identify the need to include justice and fairness in the design and use of these systems. Finally, we are going to show that including justice and fairness in the design and use of MCS is the way to maximize the interest alignment between individuals and the organization, whereas when justice and fairness are absent, interest alignment is reduced to its possible minimum. 


\section{ALIGNING PARTICULAR INTERESTS WITH THE COMMON GOAL AS THE MAIN OBJECTIVE OF MCS}

An organization lacking any form of control is impossible (Tannenbaum, 1968). Management tasks include setting goals, monitoring performance, evaluating results, and adequately compensating through rewards and possible penalties (Anthony $\sigma^{\circ}$ Govindarajan, 2003). The inclusion of informal elements becomes necessary when the environment is unstable and uncertain (Simons, 1995).

As already mentioned, the main objective of MCS is to try to generate the maximum possible goal congruence as the term was coined by Anthony $\sigma^{\circ}$ Govindarajan (2003). For Anthony $\mathscr{\sigma}^{2}$ Govindarajan,

in a process with goal congruence, the actions that people take in accordance with their perception of personal interest are generally in the best interest of the organization (Anthony $\mathscr{E}^{\circ}$ Govindarajan, 2003, 98).

And generally speaking, MCS should at least "not push people against the interests of the organization"(Anthony $\sigma^{\circ}$ Govindarajan, 2003, 98). This latter part seems obvious but it is not, as sometimes what is being proposed is an incentive system that is short-sighted, which means that it pursues short-term organizational interests while disregarding the longterm ones, thus focusing solely on short-term goal congruence.

In a discussion regarding the importance of goal congruence for MCS, Vancil proposed that "the controller must select objectives and measures, so that a good decision by a manager is itself a good decision for the organization as a whole" (Vancil, 1973, 77). Vancil defines goal congruence in terms of how the systems should be designed by the controller.

Some years earlier, in a management classic, Chester Barnard claimed that the key element of control lies in creating routines and processes that achieve individuals' participation in attaining common goals (Barnard, 1938). If those common objectives are internalized by each worker, the workers can individually balance their personal goals with the organizational goals. In doing this, the interests of workers become partially aligned, a term that has recently been defined by Gottschalg and Zollo, as the "extent to which organizational members are motivated to act in line with the objectives of the organization" (Gottschalg $6^{\circ}$ Zollo, 2007, 420). 


\section{OBJECTIVES FOR JUSTICE: CREATING SYSTEMS AND DECI- SIONS CONDUCIVE TO COMMON OBJECTIVES THAT BENEFIT EVERYONE}

As mentioned in the introduction, the area within human resources management that studies how people perceive decisions and outcomes that affect them as being just/unjust and fair/unfair is called organizational justice (Greenberg, 1990, Ambrose $\sigma^{\circ}$ Arnaud, 2005, Greenberg $\sigma^{\circ}$ Cropanzano, 2001, Fortin, 2008). Organizational justice has been studied through the perceptions of justice. The theories used by organizational justice scholars were basically grounded on the classical studies of ethicists and philosophers, as they are based on the constructs and variables applied in the perceptual domain (as an example, see the inequity theory of Adams based on Aristotle, Adams, 1965).

Therefore, ethicists have devised ways of creating systems with the requirement of justice in order to generate a greater good and ultimately happiness. A well-ordered society needs to be based on systems that promote justice amongst its citizens. This focus on perceptions has been widely used, as it strengths how is received what is applied, while the conceptual aspects have been taken from a more conceptual type of reasoning. In both cases, it is assumed that promoting justice and avoiding injustice is crucial to generating organizations that support individuals in creating a greater good for the whole (Habermas, 1990, Finnis, 1980, Aristotle, 2000).

One of the first definitions of justice appeared in Plato's thinking (Plato, The Republic). Plato believed justice has to be the limit that protects people from the abuse of power, in contrast to the law of the stronger. Aristotle develops his concept of justice in his fifth book on Nichomachean Ethics. In a less idealistic way, he goes well beyond the Platonic concepts and attributes to justice the merit of building a society where people can develop in harmony. Aristotle's systematic approach is applicable to our discussion, since it posits that justice must be found in the standards of the organizational systems (specifically, the law) and how they are used.

According to Aristotle, there are two key concepts related to justice: the justice of the system and justice of the person who is using the system. Aristotle suggests that systems must contain rules that need to follow fair guidelines, but argues that the virtue of justice is a fundamental and necessary part of the character of the decision-maker. He also stresses the 
point that the decision-maker must go beyond the mere application of the rule to adapt it to contingencies of each particular situation and person, this being the virtue of the just.

The fundamental guideline is the nature of distribution. To have just distribution, the decision-maker must give to each what they deserve, following some relevant criteria contingent upon that particular situation. The merit aspect is very important in Aristotelian thinking, and it is still valid today, when there are myriad cases in which someone does not deserve what they receive, or the opposite, they do not receive what they deserve. One example is the case of managers leading a company to bankruptcy because they are pursuing personal profits that were apparently good for the company in the short term, but that required public funds to avoid worse consequences in the long run. Doing this has produced a socialization of losses and an individual appropriation of gains that has traditionally been considered unfair. Those managers were receiving a large share of the whole pie without deserving it, running counter to Aristotle's idea of justice.

To Aristotle, merit has a wide and comprehensive meaning.

For example, a seller may deserve greater compensation if he has sold more, or may need more resources to do a specific task. Thus, merit can be linked to effort, results, needs, and any kind of contribution that people make that deserve some slice of the pie. In general, two people with the same merit should receive the same amount, and should they not, some justification is required (Aristotle, 2000). This second aspect is aimed at avoiding arbitrariness, thereby preventing injustice and unfairness.

One key point here is how to make these merit criteria explicit. Some theories have assumed implicit merit criteria but have not justified their choice in terms of justice. This in itself is unfair and matches the criterion of merit as determined by the market in economic theories. Following this type of reasoning, it is fair that each person receives what the market would give her for what she has done (her contribution).

But apart from the need to make this criterion explicit, it is also necessary to look at another drawback of market justice criterion, namely the assumption that there is always a market in which everything can be sold and bought, which is ethically difficult to uphold. Not everything that can be exchanged has a price. Generally speaking, exchanges of scarce resources cannot follow the market justice rule straightforwardly and instead requires another rule of justice. Another example is when intangibles are being exchanged. Setting prices for intangibles is complicated, and 
sometimes people are motivated to exchange these intangible resources for reasons that go beyond purely economic ones. In short, there are two considerations of fairness: being explicit by stating the justice criterion, and considering the assumptions behind this criterion in order to allow possible criticism of it, as well as proposals for alternative justice criteria.

Aristotle considers justice a virtue defined as "that state of character that makes people willing to do what is right, and have the desire for what is right" (Aristotle, 2000, 109). Aristotle considers the virtue of justice as the most important virtue, as it is absolutely necessary for cooperation (Aristotle, 2000, 129). Since Aristotle, other researchers have considered virtues in general and justice in particular as necessary to improve current societal arrangements (Flyvbjerg, 1998) and to arrive at a society that can allow for happiness and smoother relationships among members (Finnis, 1980).

Other philosophers that have studied social justice include John Rawls, perhaps one of the most influential (Rawls, 1971, 2003). In his theory of justice, with justice recently revised as fairness, Rawls suggested incorporating justice into the founding principles of a society that he believed they generate the best results for its members. Rawls was not specific in considering justice at the personal level in the system design and user because he believed that with his provisions of justice in the set-up of society, the society will be just by definition. Thus, Rawls excludes the possibility of a society that follows his just requirements but that may nonetheless lead to unjust consequences of decisions. This is a huge leap of faith that has been criticized by researchers, as it ignores the criticism of today's societal arrangements and the results of current systems in terms of fairness. Rawls seems to justify the current state of affairs with his theory, and this has been the main critique of his proposal.

We think it is necessary to distinguish between justice ex-ante and fairness ex-post. Recent thinkers suggest that there are two ways of looking at justice: discourse ethics and the force of better argument to design societal arrangements (Habermas, 1990) or alternatively, to contrast and discuss current injustices and propose contingent improvements to solve each of them (Foucault, 1988), mainly including conflict and critique arguments. We think both aspects are necessary: constitution writing is closer to our idea of justice in the design of MCS, while discussing current injustices and proposing improvements is closer to our idea of justice in the use of MCS. Both aspects are ex-ante characteristics of the design of MCS and the way managers use them afterwards. And these elements of justice in 
the design and use of MCS, in turn, affect the way people are motivated to pursue individual goals that are aligned with the organizational goals.

After surveying the literature concerned with justice, we next examine the need for justice specifically as a fundamental element of MCS. With regard to the relationship between justice and MCS, the most compelling argument for the need of justice in MCS was put forth by Williams (Williams, 1987). Williams' argument is that MCS problems are distributive in nature: "justice is a necessary concept", and "to deliberate about justice is inevitable" (Williams, 1987, 178). He continues by adding that the decision-maker "should incorporate decision modes that incorporate morals, and cultivate ways for this inclusion" (Williams, 1987, 185). A few years later, Pallot (1991) also claimed that the key ethical aspects of control systems should be related to justice. Both researchers agree that justice is fundamental and that there is a need to explicitly include it in MCS, but they did not suggest a specific way to include it.

Organizational justice researchers have based their studies on perceptions of justice. Perceptions of (in)justice have been measured for process and organizational decisions that affect people (see, for instance, the studies by Greenberg, 1987, Fortin, 2008). The findings have elucidated aspects of the outcomes of processes that individuals perceive as important when judging their fairness (Adams, 1965). Other researchers have concentrated on why people find justice important, and they argue that three main motives for justice seem to be fundamental: instrumental, relational, and moral (Folger, 1998). People pursue instrumental motives because caring about justice leads to particular individual gains (very close to outcome favorability). People pursue relational motives when they care about justice in the treatment received from those individuals they consider to be members of a desired group of reference. Ultimately, they want to continue belonging to that group, and receiving unjust treatment threatens this membership, whereas receiving just treatment reinforces it. Finally, the moral motive entails finding justice important because justice is a desired end in itself. Studies in organizational justice also focus on the process of forming perceptions of justice to show the different steps people follow (Folger $\sigma^{\circ}$ Cropanzano, 2001).

The empirical data suggest two basic things. First, people perceive that systems must include certain features to be considered fair (Blader $\sigma^{\circ}$ Tyler, 2003), and secondly, management decisions must incorporate certain elements to be considered fair (Bies, 2001). Therefore, research into organizational justice also finds it necessary to incorporate the two 
dimensions being argued here. We call justice in the design of MCS formal justice, and justice in the use of MCS informal justice.

We will turn next to show that these two dimensions of justice, both formal and informal, may lead to different levels of interest alignment between the organization and employees. What is more, the maximum interest alignment is achieved when formal justice and informal justice are present at the same time.

\section{JUSTICE IN THE DESIGN AND USE OF MANAGEMENT CONTROL SYSTEMS ALLOWS FOR BETTER ALIGNMENT OF INTERESTS}

The characteristics of justice in the formal elements of any organizational system lead to possible considerations of individual interests in the control process (Simon, 1964). The processes and criteria for granting rights must avoid arbitrariness and be consistent in order to generate perceptions of justice (Leventhal et al., 1980), and at the same time they must be transparent in terms of the standards being used (Van den Bos et al., 1996). These processes need to include ways to allow individual participation and involvement (Libby, 2001) by assessing what is really important for the organization to achieve, not only what is desirable in terms of the MCS. We think that all these requirements are considerations of justice in the design of MCS, and all of them allow people to contribute to the organizational goals. This aspect of formal justice in MCS is a necessity that contributes to aligning the interests of the organization and its members.

In addition, the members of the organization should be able to influence the variables used to evaluate their performance;

a manager must believe that the measures to assess their performance include aspects in which they can exercise some control and remove those for which he does not have any possible control (Vancil, 1973, 77).

In general, perfect control is neither possible nor desirable, but some influence on the variables that measure managerial achievements is essential. However, in uncertain environments, assessing managers' performance in areas over which they cannot exert full control may be desirable (Giraud et al., 2008). It seems reasonable that managers must exert some influence on those variables used to assess their performance, and this is an aspect 
of formal justice in the design of MCS. This aspect is needed to increase individuals' willingness to contribute to the organizational goals.

Some researchers have stated that the justice dimension must also consider the minimum below which would be unworthy to compensate employees (Scott et al., 2001, Rawls, 1971, Rawls, 2003). In addition, differences among people doing similar jobs or even differences amongst the members of the same organization in different situations of responsibility should also be limited (Siegel $\sigma^{\circ}$ Hambrick, 2005). Systematically generating inequality means that those members that benefit the least become unmotivated and dissociate themselves from the organization's mission (Siegel $\mathscr{E}^{\circ}$ Hambrick, 2005). The consequences of pay inequalities cannot be ignored, and they cause disassociation for those that earn lower pay because they are implicitly considered low performers, whereas this is not always the case (Fredrickson et al., 2010). Limiting lower pay and the differences between pay is a formal aspect of justice in the design of the MCS. If not taken into account, these aspects can create retaliation and thus a lower commitment individuals to align their goals with those of the organization (Greenberg, 1982).

In the paragraphs above, we have examined the elements of formal justice of the design of MCS, and we have argued that they contribute to aligning individual interests with organizational goals.

The last aspect to be considered as an element of formal justice is reparations for injustice. If MCS does not include ways of offsetting the effects of injustice, people may become totally disengaged with the organizational goals. Facilitating reparations for injustice is crucial but often ignored, and it is usually left to legal provisions that lie outside the company (such as the case of an employee that files a claim against the organization but does so via the legal system, not by using internal MCS processes). Systems need to have measures that amend injustices since it is impossible to have a perfectly just system in all possible situations and at all times (Wenzel et al., 2008).

At this point, it seems that including all these elements of formal justice in the design of a MCS is enough to arrive to a maximum level of interest alignment. But researchers have shown that in fact this is insufficient. In general, MCS based only on formal rules are not optimal in the case of activities that cannot be observed or results that cannot be measured (Ouchi, 1979). Moreover, organizational contracts are usually incomplete and anticipate no possible future contingencies (Milgrom $6^{\circ}$ Roberts, 1992, 256). Even if the formal system includes the reparation 
of injustices (formal justice facet of reparation), the time between the moment that the injustice happened and the moment that the system reaches possible reparation can be long enough that it could be considered an injustice in itself.

Therefore, managerial participation is necessary to adapt decisions according to justice criteria (Bies $6^{\circ}$ Moag, 1986, Bies, 1987). We have labeled this informal justice, and it is essential, for example, in preventing arbitrary decisions (Posthuma $\sigma^{\circ}$ Dworkin, 2000). To this end, all workers should be treated equally under equal circumstances, and any inequality when taking a particular decision deserves an explanation that must be given to the recipient (Sen, 1992).

Informal justice in combination with formal justice may help in two ways. First, managers that include the provision of justice in their decision-making will consider personal circumstances and then take them into account when applying MCS to reach a solution (Aristotle, 2000). Secondly, with informal justice managers may try to explicitly facilitate the restoration of justice by shortening the time between the instance of injustice and its proposed solutions and/or by ultimately trying to revamp the formal justice of the current MCS when it starts to be considered obsolete (Chomsky $\sigma^{2}$ Foucault, 1974). In fact, power is needed to update the justice of the current MCS, and informal injustice is crucial for this to happen. Moreover, if informal justice is not included, workers' commitment will decrease because they could believe that managers use arbitrary decisions to benefit themselves. This, then, will lead employees to act the same, following the example of their managers, and ultimately they will pursue their own personal interests whenever there is a conflict between them and the organization.

It is necessary to have formal justice in the design of MCS in combination with informal justice in the use of the MCS to allow individuals to align their individual interests with those of the organization. And this leads to the consideration that all things being equal, when both types of justice are present in the MCS, interest alignment reaches its maximum.

\section{CONCLUSIONS}

MCS have formal elements in their design and informal elements that can be associated with their use. MCS are the main tool to encourage the members of the organization to act according to shared goals. 
In general, justice is considered a key element of MCS, but it has been imported partly on empirical grounds and mainly by studying the perceptions of justice. But justice has not been conceptualized as the key element to create shared interests between individuals and the organization.

We have surveyed the research on justice and shown that justice is conceptualized as a key element in the design and implementation of processes. After that, we justified the inclusion of these two facets of justice (design and use) in the MCS, making it possible to generate MCS with a design and use that increase the alignment of interests between the employees and the organization.

In this sense, considering justice in the design and use of MCS reinforces the practical function of management. MCS must be designed in accordance with justice, but the discretion (subjectivity) of the manager is still necessary, and therefore a fair use of the system is essential. With formal justice only in the design, the act of improving the system is unlikely to happen. With informal justice only in the use, arbitrariness is more likely, since the employees will depend on managerial subjectivity in decision-making and they will not have a few basic rights guaranteed. Moreover, if there is no informal justice, provisions concerning reparations of injustice are not provided, nor are possible improvements in the MCS in terms of formal justice.

\section{BIBLIOGRAPHY}

Adams, J. S. (1965) Inequity in social exchange. In Berkowitz, L. (Ed.) Advances in experimental social psychology. Academic Press, NY.

Ambrose, M. L. $\sigma^{\circ}$ Arnaud, A. (2005), "Are procedural justice and distributive justice conceptually distinct?” In Greenberg, J. $\sigma^{\circ}$ Colquitt, J. A. (Eds.), Handbook of Organizational Justice. Lawrence Erlbaum, Mahwah, NJ.

Anthony, R. N. $\sigma^{\circ}$ Govindarajan, V. (2003), Management Control Systems, McGraw Hill.

Aristotle (2000), Nicomachean Ethics. The Internet Classics Archive by Daniel C. Stevenson.

Barnard, C. I. (1938), The Functions of the Executive, Harvard University Press, Cambridge, Mass.

Bies, R. J. (1987), "Beyond voice: The influence of decision-maker justification and sincerity on procedural fairness judgments". Representative Research in Social Psychology 17, 3-14. 
Bies, R. J. (2001), "Interactional (in)justice: The sacred and the profane". In Greenberg, J. $\sigma^{\circ}$ Cropanzano, R. (Eds.), Advances in Organizational Justice. Stanford University Press, San Francisco.

- Eे Moag, J. (1986), "Interactional justice: Communication criteria of fairness". In Lewicki, R., Sheppard, B. Eं Bazerman, M. (Eds.), Research on Negotiation in Organizations. JAI Press, Greenwich.

Bisbe, J. Eं Otley, D. (2004), “The effects of interactive use of management control systems on product innovation”. Accounting, Organizations and Society 32, 789-820.

Blader, S. $6 \sigma^{\circ}$ Tyler, R. (2003), “A four-component model of procedural justice: Defining the meaning of a fair process". Personality and Social Psychology Bulletin, 747-758.

Colquitt, J. A., Conlon, D. E., Wesson, M. J., Porter, C. O. $\vartheta^{\circ}$ Yee $\mathrm{Ng}, \mathrm{K}$. (2001), "Justice at the millennium: A meta-analytic review of 25 years of organizational justice research". Journal of Applied Psychology 86, 425-445.

Cugueró-Escofet, N. $6 \sigma^{\circ}$ Rosanas, J. (2011), "Research on Management Control Systems, Fairness and Justice: An analytical review". Working paper, IESE Business School.

Chapman, C. S. (1998), “Accountants in Organizational Networks". Accounting, Organizations and Society 23, 737-766.

Chomsky, N. $\sigma^{\circ}$ Foucault, M. (1974), "Human Nature: Justice versus Power". In Elders, F. (Ed.) Reflexive Water: The Basic Concerns of Mankind. Souvenir, London.

Dávila, T. (2000), "An empirical study on the drivers of management control systems' design in new product development". Accounting, Organizations and Society 25, 383-409.

- (2005), "An exploratory study on the emergence of management control systems: Formalizing human resources in small growing firms". Accounting, Organizations and Society, 223-248.

—, Foster, G. Eं Oyon, D. (2009), “Accounting and Control, Entrepreneurship and Innovation: Venturing into New Research Opportunities". European Accounting Review 18, 281-311.

Epstein, M. $6^{\circ}$ Manzoni, J. F. (1997), "The balanced scorecard and tableau du bord: Translating strategy into action". Management Accounting 79, 28-36.

Finnis, J. (1980), Natural Law and Natural Rights, Clarendon Press, Oxford. 
Flyvbjerg, B. (1998), "Habermas and Foulcault: Thinkers for civil society?”, British Journal of Sociology 49, 210-233.

Folger, R. (1998), "Fairness as a moral virtue". In Schminke, M. (Ed.) Managerial Ethics: Moral Management of People and Processes. Lawrence Erlbaum, Mahwah, NJ.

- $\sigma^{\circ}$ Cropanzano, R. (2001), "Fairness theory: Justice as accountability". In Greenberg, J. $6 \sigma^{\circ}$ Cropanzano, R. (Eds.), Advances in Organizational Justice. Stanford University Press, Stanford, CA.

Fortin, M. (2008), "Perspectives on organizational justice: Concept clarification, social context integration, time and links with morality". International Journal of Management Reviews 10, 93-126.

Foucault, M. (1988), "The Ethic of Care for the Self as a Practice of Freedom". In Bernauer, J. E๑ Rasmussen, D. (Eds.), The Final Foucault. MIT Press, Cambridge, Mass.

Fredrickson, J. W., Davis-Blake, A. छ Sanders, W. M. G. (2010), "Sharing the wealth: Social comparisons and pay dispersion in the CEO's top team". Strategic Management Journal 31, 1031-1053.

Giraud, F., Langeving, P. $6^{\circ}$ Mendoza, C. (2008), "Justice as a rationale for the controllability principle: A study of managers' opinions". Management Accounting Research 19, 32-44.

Gottschalg, O. $\sigma^{\circ}$ Zollo, M. (2007), "Interest alignment and competitive advantage". Academy of Management Review 32, 418-437.

Greenberg, J. (1982), "Approaching equity and avoiding inequity in groups and organizations". In Greenberg, J. $\sigma^{\circ}$ Cohen, R. L. (Eds.), Equity and Justice in Social Behaviour. Academic Press, NY.

- (1987), "A Taxonomy of Organizational Justice Theories". The Academy of Management Review 12, 9-22.

- (1990), "Organizational justice: Yesterday, today, and tomorrow". Journal of Management 16 (2), 399-432.

- $\sigma^{\circ}$ Cropanzano, R. E. (2001), Advances in Organizational Justice, Stanford University Press.

Habermas, J. (1990), Moral Consciousness and Communicative Action, MIT Press, Cambridge, Mass.

Kaplan, R. S. $\sigma^{\circ}$ Norton, D. (1992), “The balanced scorecard: Measures that drive performance". Harvard Business Review, 70, 71-79.

- (1993), "Putting the Balanced Scorecard to work". Harvard Business Review 71, 134-147.

Kaplan, R. S. $\sigma^{\circ}$ Norton, D. P. (1996), "Using the balanced scorecard as a strategic management system". Harvard Business Review, 75-85. 
Leventhal, G. S., Karuza , J. $6^{\circ}$ Fry, W. R. (1980), "Beyond Fairness: A theory of allocation preferences". In G. Mikula (ed.), Justice and Social Interaction. Springer-Verlag, NY. 167-218.

Libby, T. (2001), "Referent Cognitions and Budgetary Fairness: A Research Note". Journal of Management Accounting Research 13, 91-105.

Milgrom, P. $\sigma^{\circ}$ Roberts, J. (1992), Economics, Organizations and Management, Prentice-Hall International, Inc.

Ouchi, W. G. (1979), "A Conceptual Framework for the Design of Organizational Control Mechanisms”. Management Science 25, 833-848.

Pallot, J. (1991), “The Legitimate Concern with Fairness: A Comment”. Accounting, Organizations and Society 16 (2), 201-208.

Plato, The Republic. New Haven, Yale University Press.

Posthuma, R. A. E9 Dworkin, J. B. (2000), "A Behavioral Theory of Arbitrator Acceptability". International Journal of Conflict Management (1997-2002) 11, 249.

Rawls, J. (1971), A Theory of Justice, The Belknap Press of Harvard University Press.

- (2003), Justice as Fairness: A Restatement. The Belknap Press of Harvard University Press.

Scott, J. T., Matland, R. E., Michelbach, P. A. $\mathscr{G}^{\circ}$ Bornstein, B. H. (2001), "Just Deserts: An Experimental Study of Distributive Justice Norms". American Journal of Political Science, 45, 749-767.

Sen, A. (1992), Inequality Reexamined, Harvard University Press. Siegel, P. A. $\Xi^{2}$ Hambrick, D. C. (2005), "Pay Disparities within Top Management Groups: Evidence of Harmful Effects on Performance of High-Technology Firms”. Organization Science 16, 259-274.

Simon, H. (1964), On the concept of Organizational Goal. Administrative Science Quarterly 9, 1-22.

Simons, R. (1995), Levers of Control. Harvard Business School Press, Boston.

Tannenbaum, A. S. (1968), Control in Organizations. McGraw-Hill, New York.

Vand den Bos, K., Vermunt, R. $\sigma^{\circ}$ Wilke, H. A. M. (1996), “The consistency rule and the voice effect: The influence of expectations on procedural fairness judgements and performance". European Journal of Social Psychology 26, 411-428.

Vancil, R. F. (1973), What kind of management control do you need? Harvard Business Review 51 (2), 75-86. 
Wenzel, M., Okimoto, T. G., Feather, N. T. $\sigma^{\circ}$ Platow, M. J. (2008),

"Retributive and restorative justice". Law and Human Behavior 32, 375-389.

Williams, P. F. (1987), “The legitimate concern with fairness”. Accounting, Organizations and Society 12 (2), 169-189.

Natalia Cugueró-Escofet IESE Business School - University of Navarra ncuguero@iese.edu Josep Maria Rosanas IESE Business School - University of Navarra jrosanas@iese.edu

This paper was received on October 14, 2011 and was approved on January 25, 2012 